\title{
ADDITIONS TO THE CHECKLIST OF SASKATCHEWAN BIRDS SINCE 1969
}

C. STUART HOUSTON, MARY I. HOUSTON, 863 University Drive, Saskatoon, Saskatchewan, S7N 0J8 and J. BERNARD GOLLOP, Canadian Wildife Service, 115 Perimeter Road, Saskatoon, Saskatchewan. S7N 0X4

The fifth edition of the Field Check-list of Saskatchewan Birds, published by the Saskatchewan Museum of Natural History in June 1969, listed 325 fully accepted species and 15 hypothetical species. Since then, a surprising number of additions to the provincial list have been reported. We are reminded of Newman's 1976 prediction, with tongue only lightly in cheek, that "... given enough time all the species of birds in North America will be recorded from all the states." ${ }^{66}$ Newman, in turn, quoted Joseph B. Grinnell as the first man to recognize this phenomenon in 1922, when Grinnell calculated that by the year 2331 the California list, at the 1922 rate of additions, would contain all North American bird species. ${ }^{19}$

In the early years of ornithology, a specimen was required before a species could be added to any full provincial list. When Mitchell published his "Birds of Saskatchewan" in the Canadian Field-Naturalist in 1924, he listed 265 fully accepted species plus 29 hypothetical species and nine additional, recognizable subspecies. ${ }^{33}$ In 1943, L. B. Potter's list noted specimen records for 15 of the previously hypothetical species and added specimen records for seven more: American (Great) Egret, Hudsonian Curlew (Whimbrel), Rufous Hummingbird, Calliope Hummingbird, Green-tailed Towhee, Black-throated Blue Warbler, and Mockingbird. ${ }^{39}$ Potter also listed a personal sight record of the Pinyon Jay, and E. H. M. Knowles' suposed observation of a Black Vulture, based on Knowles' admitted lack of knowledge of the immature plumage of the Turkey Vulture at that time. The provincial list was growing (Table 1).

In 1947, the Yorkton Natural History Society had an opportunity to use type already set for the Manitoba Natural History Society's Check-list, adding and deleting a few species as necessary. This was based on Potter's additions, but adding the Oregon Junco which had achieved full species status in the Fourth American Ornithologists' Union (AOU) Check-list of 1931, the American or Northern Three-toed Woodpecker on the basis of a 1939 Regina specimen, and three introduced species, the Ringnecked Pheasant, Chukar and Starling.

In February 1954 the second edition of this check-list, compiled by F. G. Bard and C.S. Houston, was published by the museum with the cooperation of the Yorkton, Prince Albert and Regina Natural History Societies. The printer was asked to substitute "Pink-sided Junco" in place of the unconventional species name of "Red-backed Junco" used by Taverner in Birds of Canada, ${ }^{51 a}$ but in error both names appeared. Four formerly hypothetical species were now given full status: Pacific (Arctic) Loon, Great Gray Owl, Yellow-throated Vireo and Scarlet Tanager, the first three on the basis of specimens and the latter on the basis of numerous sight records by competent observers of an easily recognized species. Harlan's Hawk was now added. since it was listed as a full 


\begin{tabular}{|c|c|c|}
\hline & $\begin{array}{r}\text { Fully } \\
\text { accepted }\end{array}$ & Hypothetical \\
\hline 1924 List $^{33}$ & 265 & 29 \\
\hline 1943 List $^{39}$ & 287 & 15 \\
\hline 1947 List $^{55}$ & $292^{*}$ & 13 \\
\hline 1954 List $^{3 \mathrm{a}}$ & $297^{* *}$ & 11 \\
\hline 1958 List $^{27}$ a & 304 & 12 \\
\hline 1959 List $^{27 b}$ & 308 & 12 \\
\hline 1969 List $^{1 \mathrm{a}}$ & 325 & 15 \\
\hline 1981 List & 339 & $40^{* * * *}$ \\
\hline
\end{tabular}

* The 1947 checklist stated 294 in error.

** The 1954 checklist stated 298 in error.

*** Thirty new species, plus nine holdovers from 1969 list, plus Mountain Plover, fully accredited in error in 1969 and now reduced to hypothetical status.

species by the AOU. The American Woodcock and Black Vulture were deleted from the hypothetical list, since the compilers agreed that they were based on erroneous sight records. The Varied Thrush and Field Sparrow were new to the hypothetical list. By mistake, the query marks to indicate hypothetical status were omitted from both the Mountain Plover and the Swallow-tailed Kite, this error for the Mountain Plover being perpetuated in subsequent editions.

In March 1958 and in June 1959, the third and fourth editions, each compiled by C. S. Houston, F. G. Bard and R. W. Nero, were brought out in quick succession, the fourth in time for the annual meeting of the AOU in Regina in August 1959. The third list elevated Yellow-billed Loon, Least Bittern and Parasitic Jaeger to full from hypothetical status on the basis of specimens and added Black Brant and Goldencrowned Sparrow because of specimens and Parula Warbler on the basis of a recognizable photograph. Since the dowitchers were now considered by the AOU to be two separate species, one more name was added to the list. New hypotheticals on the basis of sight records were the Little Blue
Heron, Snowy Egret, Black-necked Stilt, Pine Warbler, and Cardinal, while the Scarlet Tanager was relegated back to the hypothetical list at the insistence of the third compiler because there was no. extant specimen or photograph.

The fourth edition added two introduced species, the Mute Swan and Rock Dove, and two species with specimens, the Barred Owl and Redbellied Woodpecker, to the full list.

In June 1969 the museum published a fifth list compiled at their request by C. S. Houston, with assistance from F. G. Bard, R. W. Nero and F. H. Brazier. The 1968 proofs contained the authors' names, but the published version did not. Six species moved up from the hypothetical to the fully accepted list: Greater Scaup (which had been omitted entirely from the fourth list), Poor-will, Varied Thrush, Pine Warbler, Scarlet Tanager, and Cardinal. There were 11 new, fully accepted species: Rock Ptarmigan, Turkey (introduced), Snowy Plover, Ruff, Glaucous Gull, "Iceland Gull" (based on specimens of Thayer's Gull, briefly considered as a subspecies of the Iceland Gull), Little Gull, Williamson's Sapsucker, Violet-green Swallow, Blue- 
winged Warbler and Black-throated Gray Warbler. The nine new hypothetical species were: Green Heron, Barrow's Goldeneye, Eskimo Eurlew (based on records from the 1820's), Long-tailed Jaeger, Least Tern, Eastern Wood Pewee, Mountain Chickadee, Prothonotary Warbler, and Golden-winged Warbler.

Since 1969, 14 species have been added to the fully accepted list, while here are sightings of another 30 pecies of varying degrees of credibility. Documentation for the 14 follows, with letails of the other 30 species slated for ublication in the December 1981 issue of the Blue Jay.

\section{New, Fully Accepted Species}

(Note: an asterisk* indicates a pecies listed as hypothetical on the 5th baskatchewan Check-List; when no sterisk is present, this indicates a new pecies to the list. The cutoff date is 31 ecember 1980.)

\section{*GREEN HERON}

A single bird at the Regina Waterfowl ark was sighted first by Robyn onison on 20 May 1975, confirmed by W. Lahrman, F. H. Brazier, E. L. Fox nd Tom Beveridge, and photographed y Dwayne Harty. This individual was resent through 31 May and this or nother bird was seen in the same area n 21 June, 17 August and 6-7 eptember 1975..$^{2}$ Another individual as seen at the Regina Waterfowl Park 8-31 May 1979, studied by many oservers and photographed by R. L. cott. $^{4}$

The first Saskatchewan sighting of a reen Heron was at Radville on 22 June 966, by Cliff Matthews. ${ }^{32}$ Other ghtings of single birds have been made F. H. Brazier at Regina on 12 June $971,{ }^{26}$ at Saskatoon by D. R. M. Hatch 8 September 1977, ${ }^{4}$ at Yorkton by S. and M. I. Houston on 10 August 77 (unpublished), and at Val Marie by uart Keys on 8 September $1980 .{ }^{21}$

\section{2. *LITTLE BLUE HERON}

An adult was photographed by W. C. Harris and S. M. Lamont on 19 June 1976 at the north end of Last Mountain Lake, and the color photograph, when highly magnified, allowed positive identification. ${ }^{22}$

Previously, Joyce Gunn saw four at Good Spirit Lake on 24 May 1956; Houston and others saw one south of Yorkton on 9-21 September 1956, with a nearly identifiable photograph published; ${ }^{25}$ Peter McLellan had sightings near Arcola in 1956 and in Moose Mountain Provincial Park on 1214 June 1959:35 and Robyn Donison saw one at Regina on 1 July $1976 .{ }^{43}$

\section{CATTLE EGRET}

Dale Hjertaas found six Cattle Egrets near Maxim on 28 July 1977 and a photo by Dave Duffus placed this species on the confirmed list; up to 10 were present there through 23 August 1977. ${ }^{24}$ Another bird, seen near Richardson on 22-29 May 1978 by Tom Riffel and many observers, was the subject of a delightful photo by Gary Seib. ${ }^{4}$

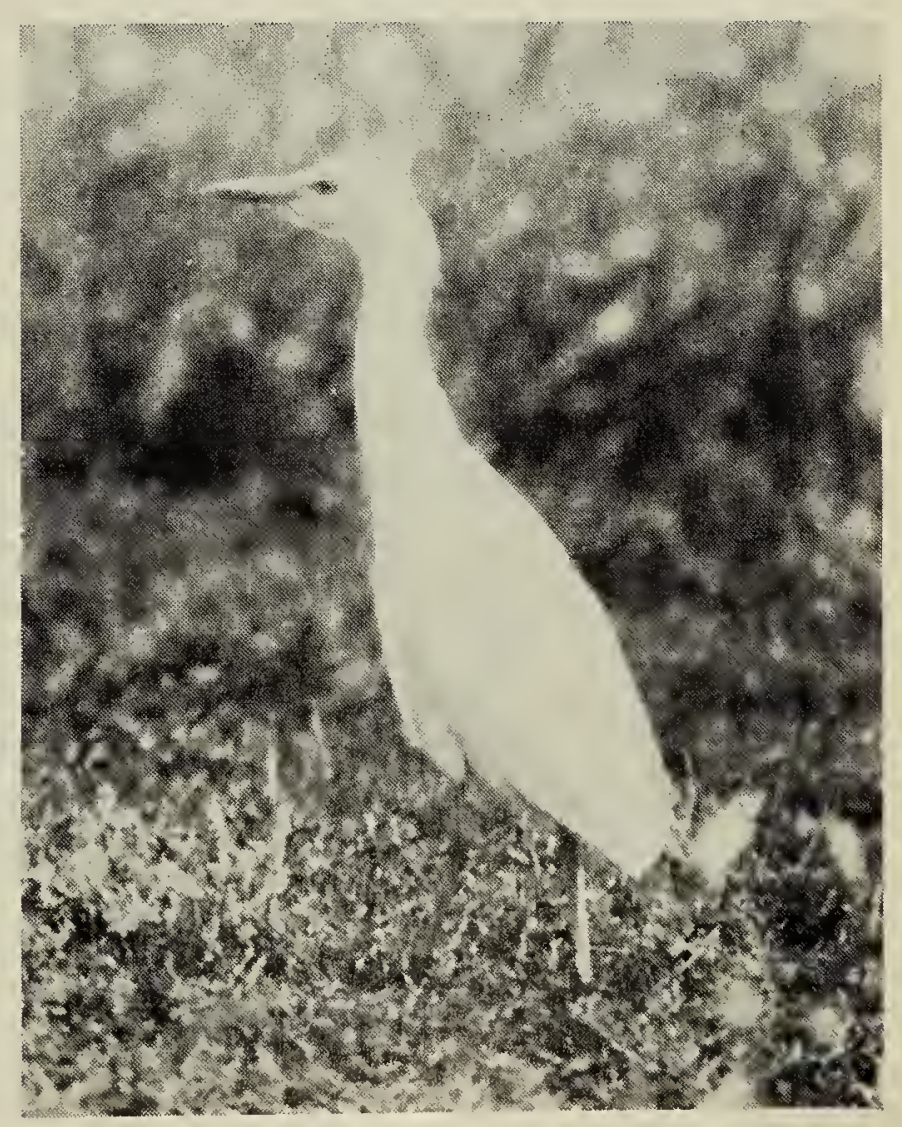

Cattle Egret.

Fred W. Lahrman 
Other Saskatchewan sightings of the Cattle Egret have included: two near Eyebrow on 14-17 June 1974 by Hugh Hedger; ${ }^{28}$ one south of the Hague ferry on 27-28 May 1978 by many observers; ${ }^{38}$ three at Kinistino on 8 June 1978 by Dennis Hooey and D. R. Smith; ${ }^{47}$ up to seven at Little Quill Lake in August 1977 by John Totten; ${ }^{14}$ one at "Buck Lake" south of Regina on 22 May 1979 by F. W. Lahrman; ${ }^{4}$ one at Spring Valley, 24-30 October 1979 by Flossie Bogdan; ${ }^{20}$ one near Dana on 9 August 1980 by W. C. Harris. ${ }^{21}$

\section{4. *SNOWY EGRET}

Don Weidl photographed a Snowy Egret at Crooked Lake in the Qu'Appelle valley on 7 May 1978, 2 days after Milton Criddle first sighted it. ${ }^{53}$

Other Saskatchewan sightings of the Snowy Egret have included: one at Good Spirit Lake on 23-27 May 1956 by Joyce Gurin and Bill Anaka; ${ }^{2}$ one east of Craven on 9 July 1956 by E. L. Fox and A. Swanston; ${ }^{2}$ one at Cypress Lake dam on 19 June 1970 by W. C. Weber; 52 one at Brightwater Reservoir south of Dundurn on 15 May 1977 by J. B. Gollop; ${ }^{45}$ two at Briercrest on 5 July 1977 by Dale
Hjertaas; ${ }^{46}$ one at Bradwell Reservoir or 3-4 June 1978 by J. B. Gollop and si others; ${ }^{47}$ one at Chapleau Lake south o Indian Head on 3 May 1979 by G. W Beyersbergen and D.J. Neiman although the latter's initials were in correct as published; ${ }^{15}$ one at Ardill of 31 May 1979 by Don Weidl, D. W Goerzen and D. W. Phillips; ${ }^{16}$ one at th north end of Last Mountain Lake on 3 May 1980 by Clint Jorgenson, Gle Vandoorne and Brenda Dale. ${ }^{17}$

\section{WHITE-FACED IBIS}

One was sighted at Stalwart Marsh o the west side of Last Mountain Lake $b$ Bob Luterbach and others on 29 MayJune 1976, and a recognizab photograph was obtained by $F . V$ Lahrman. ${ }^{29}$ That fall, Lahrman saw a immature at Valeport Marsh on 130 tober $1976 .{ }^{44}$

Brad and Jan Mason saw three at th north end of Last Mountain Lake on May $1977 .{ }^{10}$ John Totten saw up to fo at Little Quill Lake in August 1977 R. J. Long saw two near Kincaid on May 1978 and obtained a brief $16 \mathrm{~m}$ movie sequence (undated 1980 letter C. S. Houston). 
Modern sight records of the Black Scoter began with one seen by S. D. Riome at Tobin Lake on 24 and 31 October $1970 . .^{40} \mathrm{~A}$. R. Smith then saw three on 14 October and two on 15 October 1975 at Blackstrap Reservoir near Dundurn. ${ }^{37} \mathrm{~F}$. W. Lahrman photographed an adult and an immature at Condie Reservoir near Regina on 16-18 October 1976. ${ }^{4}$ M.E. Szumigalski sighted a female on the river north of Saskatoon on 12 and 15 April 1977 (card in Saskatoon bird record file, not used in Saskatoon Field Notes). An adult male was sighted at Wascana Waterfowl Park on 6 November 1978 by F.W. Lahrman, Margaret Belcher and others and was photographed by Lahrman. ${ }^{4} \mathrm{~A}$ probable adult female at Wascana Waterfowl Park on 23 and 26 October 1979 was seen by Bob Luterbach, Bob Kreba and others. ${ }^{4}$ Three were seen at Regina Beach on 1 November 1980 by Luterbach and an adult male was seen at Indian Head on 11 November 1980 by Lahrman and R. L. Scott. ${ }^{21}$

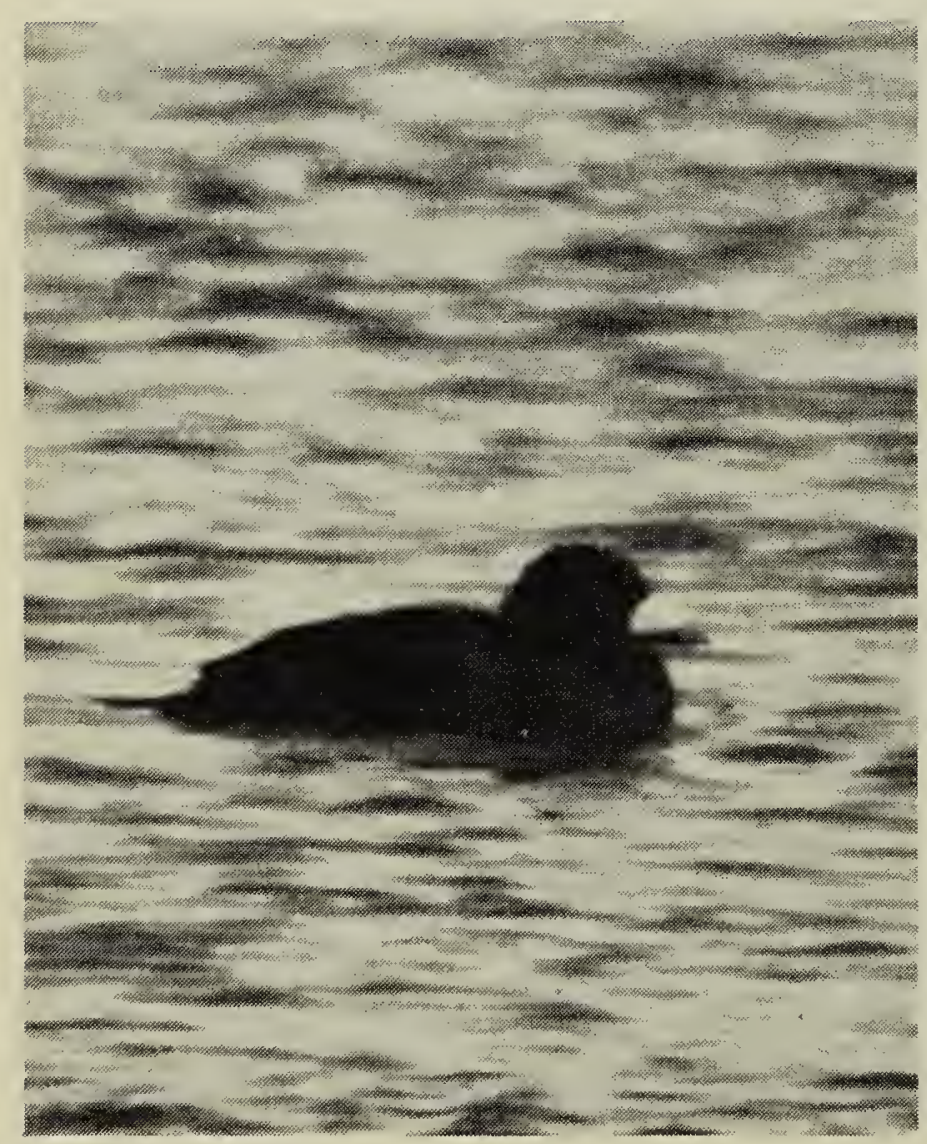

Black Scoter.

Fred W. Lahrman

\section{THAYER'S GULL}

The specimen of Thayer's Gull collected by R. W. Nero at Uranium City near Beaverlodge Lake on 9 June 1960, following the recognizable photograph of eight birds on 5 June 1960, was considered at the time to be a subspecies of the Iceland Gull, although previously it had been considered a race of the Herring Gull. ${ }^{34}$ The Iceland Gull was thereby prematurely, inappropriately and only temporarily placed on the Saskatchewan list, leading to much confusion, Nero also saw an adult Thayer's Gul near Uranium City on 1 July 1960. ${ }^{34}$

A Thayer's Gull was noted at Regine from 21 to 27 October 1980 by Bob Luterbach and Bob Kreba. ${ }^{21}$

In the 32 nd supplement to the $\mathrm{AOl}$ Check-List, Thayer's Gull was for the first time recognized as a separat species, ${ }^{1}$ thereby removing the Icelan Gull from the official Saskatchewan list

\section{SCISSOR-TAILED FLYCATCHER}

A recognizable photograph was taken by Kathy Meeres of a Scissor. tailed Flycatcher south of Saskatoon between 20-24 September 1980. It was seen by many observers after its firs sighting by J.B. Gollop and is nov placed on the fully accredited list. ${ }^{21}$

Previous Scissor-tailed sightings, a of single individuals, were at Mileston on 24 September 1970 by Mrs. Jea Bradley, ${ }^{6}$ at Lumsden on 26 Augus 1975 by A.J. MacAulay, ${ }^{30}$ and nea Tugaske on 6 June 1978 by Fran Perlett. ${ }^{23}$

\section{WILLOW FLYCATCHER}

Stein's paper in $1963,{ }^{51}$ whid proposed separation of the Trail Flycatcher into two species, th northern Alder Flycatcher and the mo southern Willow Flycatcher, was mar official by the 32 nd supplement to $t$ AOU Check-List in 1973. ${ }^{1}$ Stein ga the range of the southern race here $u$ der discussion as including northe 
North Dakota and "probably southern Saskatchewan." 51

In Saskatchewan, the commoner of these two closely related and very similar species is undoubtedly the Alder Flycatcher, which is locally common in moist willow habitat in the central part of the province, particularly near the southern edge of the mixed coniferousdeciduous forest. Henri Ouellet of the National Museum of Canada has advised that individual specimens of Willow and Alder Flycatchers cannot be distinguished in the hand. ${ }^{4}$ W. B. Robertson has warned that, at least in Ontario in 1978, "Birds of each song type occurred widely in habitat and range characteristic of the other," with the "chilling suspicion that some individuals may speak both pieces." ${ }^{41}$

A breeding specimen in the Saskatchewan Museum of Natural History, collected at Carnduff, has been ascribed to this form on the basis of locality and song, according to F. W. Lahrman. Callin found birds with the Willow song ype nesting sparingly in the Qu'Appelle valley, and R. J. Long recorded their calls at Lebret on 3 July 1974. ${ }^{11}$ Bob - uterbach reported singing birds at trawberry Lake south of Indian Head on 29 June 1975. ${ }^{11}$ S. M. Lamont eported five singing males at Nicolle Flats southeast of Buffalo Pound Lake on 28 June 1978; ${ }^{4}$ these birds were in willows spread out over nearly $1 \mathrm{~km}$ of narsh edge.

\section{1. *EASTERN WOOD PEWEE}

On 14 June 1884 Ernest E. Thompson (Seton) collected an Eastern Wood Pewee on the slopes of the Duck Mountains northeast of the present illage of Runnymede. ${ }^{27}$ This was only 2 lays after he had collected a Western Wood Pewee on his homestead, on the fouth half of 36-28-31W1, southwest of resent Runnymede. The present ocation of these specimens is unnown. Modern substantiation was ichieved when W. C. Harris taped an
Eastern Wood Pewee's song at Good Spirit Lake on 11 June 1977, and had the identity confirmed by Henri Ouellet at the National Museum of Canada. ${ }^{4}$ Bob Godwin and Brian Johns also taperecorded 20 songs of a single Eastern Wood Pewee near Saskatoon on 5 July 1978. ${ }^{4}$

E. M. Callin reports that the Eastern Wood Pewee ranges more than $80 \mathrm{~km}$ up the Qu'Appelle valley from the Manitoba boundary, east as far as Round Lake. ${ }^{11}$ Callin himself heard one at Scissor Creek where it crosses Highway 9 on 9 June 1974 and S. M. Lamont heard one each at Scissors Creek and Bear Creek on 27 and 28 July 1977. ${ }^{11}$ In 1976, D. R. M. Hatch heard eight individual Eastern Wood Pewees in a 40-km breeding bird survey between Tantallon and Round Lake."

Presumed Eastern Wood Pewee songs beyond the known breeding range have also been heard at Kenosee Lake by R.W. Nero on 17 August $1963,{ }^{35}$ at Flying Creek near Regina by $\mathrm{Al}$ and Betty Binnie on 11 May $1968,{ }^{4}$ at Fort San by E. M. Callin on 22 June $1968,{ }^{11}$ at Ranch Lake west of Naicam on 6 and 17 June 1972 by W. C. Harris, ${ }^{8}$ and at Kenosee Lake by Lars Norgren on 21 August $1975 .{ }^{42}$

Unpublished notes concerning Eastern Wood Pewee songs include one in the Pasquia Hills, $90 \mathrm{~km}$ north of Hudson Bay, on 24 June 1975 by W. C. Harris, two seen and heard at Little Kenosee Lake in Moose Mountain Provincial Park on 24 August 1975 by W. E. Renaud, Eric Tull and Allan Wiseley; one at McBride Lake on 12 June 1980 by W. C. Harris, and one at Good Spirit Lake on 13-14 August 1980 by Bill and Joyce Anaka.

\section{2. *GOLDEN-WINGED WARBLER}

This species is now fully accepted on the basis of sound recordings made in Regina by F. G. Bard on 2 June 1968 , with 21 songs recorded over 5 hours; the male singer was seen while singing 
for 30 seconds. $^{3}$ The recorded songs followed exactly the audiospectrogram given by Robbins, Bruun, Zim and Singer. ${ }^{41 a}$

There was a previous sight record for Regina by F. H. Brazier on 18 May $1962,{ }^{7}$ and a subsequent sighting by $F$. Lawrence, E. L. Fox, G. F. Ledingham, Jim and Shirley Jowsey on 1 October 1972, each in the Legislative grounds. ${ }^{4}$ Bob Luterbach saw a male at Yorkton on 30 May 1973 (pers. comm. on 5 December 1980 to C. S. Houston).

\section{ORCHARD ORIOLE}

This species is fully accepted. The first Saskatchewan sighting was of a breeding pair, a first year male and a female, near Fort Qu'Appelle on 19 June through 22 July 1974. ${ }^{9}$ These birds were found by E. M. Callin, confirmed by F. H. Brazier and Jack Lowe, tape-recorded by R. J. Long and photographed by Dwayne Harty. One young was seen after fledging.

A male in first-year plumage was seen on Vic Harper's farm, $20 \mathrm{~km}$ northwest of Saskatoon on 15 and 19 June 1980; the nest, closely suspended below the horizontal branch of a large spruce $5 \mathrm{~m}$ above the ground was located on 4 July 1980 by Chris Escott, Ron Jensen, Lawrence Baschak and Stan Shadick, and the young were being fed out of the nest on 16 and 18 July. ${ }^{49}$ This is the most northerly breeding record in North America; a colour photograph and the specific characteristics of the nest confirmed the identification. At the same time another first year male was with a female sitting on her nest in an elm, $3 \mathrm{~km}$ east of the dam across Buffalo Pound Lake, when found by Nigel Caulkett and Dale Hjertaas on 30 June $1980 .{ }^{49}$ On 12 July Stan Shadick and Lawrence Baschak found two young, one in and one out of this nest, being fed by the male. ${ }^{49}$

In addition to these three Saskatchewan breeding records, there have been a number of sight records: an adult male seen and heard by D. R. M. Hatch at the mouth of Cutarm Creek near Tantallon on 8 June 1976; ${ }^{11}$ a probable sighting at Indian Head by Ray and Rose McLaughlin on 8 June 1976; ${ }^{11}$ an immature male at the north end of Last Mountain Lake seen by W. C. Harris, Glen Vandoorne, and Brenda Dale on 30 May to 3 June $1980,{ }^{18}$ while its song was tape-recorded by Dale and Paule Hjertaas; a pair was seen at Oxbow throughout the summer of 1980 by Hazel Paton. ${ }^{18}$ First year male Orchard Orioles have been seen at Regina by $\mathrm{Al}$ and Betty Binnie on 19-25 June 1972, ${ }^{4}$ by Shirley Jowsey on 24 May 1979, ${ }^{4}$ and by Diane Secoy on 26 May $1980 .{ }^{17}$

\section{SUMMER TANAGER}

The first Saskatchewan record, with an identifiable series of photographs, was obtained by Jack and Janet Wilkinson at Frontier on 7 May $1976 . .^{54}$

'AMERICAN ORNITHOLOGISTS' UNION: 1973. Thirty-second supplement to the American Ornithologists' Union checklist of North American birds. Auk 90:411-419.

${ }^{1}$ ANONYMOUS. 1969. Check-list of Saskatchewan birds. Saskatchewan Museum of Natural History, Regina.

${ }^{2}$ ANAKA, W. 1956. The Snowy Egret (with editor's note re Little Blue Heron). Blue Jay 14:89-90.

${ }^{3}$ BARD, F. G. 1968. Taping the song of the Golden-winged Warbler. Blue Jay 26:177-178.

3a BARD, F. G. and C. S. HOUSTON. 1954 Check-list of Saskatchewan Birds Saskatchewan Museum of Natura History, Regina.

${ }^{4} \mathrm{BELCHER}$, M. 1980. Birds of Regina. Revis ed edition, Regina: Sask. Nat. Hist Soc., Spec. Publ. No. 12. 151 pp.

${ }^{5} \mathrm{BELL}, \mathrm{R} .1882$. Notes on the birds of Hud son's Bay. Proc. Roy. Soc. Canad 4:49-54.

${ }^{6}$ BRADLEY, J. E. 1971. A sight record of th Scissor-tailed Flycatcher for souther Saskatchewan. Blue Jay 29:34. 
'BRAZIER, F. H. 1962. A Golden-winged Warbler in Regina. Blue Jay 20:153154.

${ }^{8}$ CALDWELL, R., R. MacLENNAN, W. HARRIS and H. WOLOWSKI. 1973. An ecological survey of Ranch Lake, Saskatchewan, Mimeographed, $61 \mathrm{pp}$.

${ }^{9}$ CALLIN, E. M. 1975. First records of the Orchard Oriole in Saskatchewan. Blue Jay 33:176-177.

${ }^{10}$ CALLIN, E. M. 1978. White-faced Ibis at Last Mountain Lake, Saskatchewan. Blue Jay 36:123.

${ }^{11 C A L L I N . ~ E . ~ M . ~ 1980 . ~ B i r d s ~ o f ~ t h e ~}$ Qu'Appelle, 1857-1979. Regina: Sask. Nat. Hist. Soc., Spec. Publ. No. 13.

${ }^{12}$ DONISON, R. 1977. First confirmed Green Heron for Saskatchewan. Blue Jay 35:45-46.

${ }^{13}$ EVANS, M. E. and W. J. L. SLADEN. 1980. A comparative analysis of the bill markings of Whistling and Bewick's Swans and out-of-range occurrence of the two taxa. Auk 97:697-703.

${ }^{14}$ GOLLOP, J. B. 1978. White-faced Ibis and Cattle Egret at Little Quill Lake. Blue Jay 36:122.

${ }^{15}$ GOLLOP, J. B. 1979. Prairie Provinces Region. American Birds 33:781-782.

${ }^{16}$ GOLLOP, J. B. 1979. Prairie Provinces Region. American Birds 33:872-873.

${ }^{17}$ GOLLOP, J.B. 1980. Prairie Provinces Region. American Birds 34:787-789.

${ }^{18}$ GOLLOP, J. B. 1980. Prairie Provinces Region. American Birds 34:905-906.

${ }^{19}$ GRINNELL, J. 1922. The role of the "accidental." Auk 39:373-380.

${ }^{20}$ HARRIS, W. C. 1980. Prairie Provinces Region. American Birds 34:172-174.

${ }^{21}$ HARRIS, W. C. 1981. Prairie Provinces Region. American Birds 35: in press.

${ }^{22}$ HARRIS, W. C. and S. M. LAMONT. 1977. Little Blue Heron in Saskatchewan. Blue Jay 35:90.

${ }^{23}$ HEDGER, H. 1979. Scissor-tailed Flycatcher at Tugaske, Saskatchewan. Blue Jay 37:128.

${ }^{24}$ HJERTAAS, D. G. 1979. The Cattle Egret arrives in Saskatchewan. Blue Jay 37:104-107.
${ }^{25}$ HOUSTON, C.S. 1957 . The Little Blue Heron in Saskatchewan. Blue Jay 15:52.

${ }^{26}$ HOUSTON, C. S. 1971. Northern Great Plains Region. American Birds 25:869872.

${ }^{27}$ HOUSTON, C. S. 1980. (Introduction to) Ernest Thomson Seton in Manitoba, 1882-1892. Winnipeg: Manitoba Naturalists Society.

27 a HOUSTON, C. S., F. G. BARD and R. W. NERO. 1958. Check-list of Saskatchewan birds. Saskatchewan Museum of Natural History, Regina.

27 b HOUSTON, C. S., F. G. BARD and R. W. NERO. 1959. Check-list of Saskatchewan birds. Saskatchewan Museum of Natural History, Regina.

${ }^{28}$ HOUSTON, C. S. and M.I. HOUSTON. 1974. Northern Great Plains Region. American Birds 28:915-918.

${ }^{29}$ LAHRMAN, F. W. 1976. White-faced Ibis in Saskatchewan. Blue Jay 34:238.

${ }^{30}$ MacAULAY, A. J. 1976. Sight record of the Scissor-tailed Flycatcher for Saskatchewan. Blue Jay 34:95.

${ }^{31}$ MACFARLANE, R. 1908. Notes on the mammals and birds of northern Canada, In: Through the Mackenzie Basin, by C. Mair. Toronto: William Briggs.

${ }^{32}$ MATTHEWS, C. A. 1967. Possible sighting of a Green Heron. Blue Jay 25:24.

${ }^{33}$ MITCHELL, H. H. 1924. Birds of Saskatchewan. Can. Field-Nat. 38:101-118.

${ }^{34}$ NERO, R. W. 1963. Birds of the Lake Athabasca region, Saskatchewan. Regina: Sask. Nat. Hist. Soc. Spec. Publ. No. 5.

${ }^{35}$ NERO, R. W. and M. R. LEIN. 1971. Birds of Moose Mountain, Saskatchewan. Regina: Sask. Nat. Hist. Soc., Spec. Publ. No. 7.

${ }^{36}$ NEWMAN, R.J. 1976. The Changing Seasons - the nesting season, 1976. American Birds 30:920-925.

${ }^{37}$ O'NEIL, P. 1975. Saskatoon Field Notes 18:2.

${ }^{38}$ O'NEIL, P. 1978. Saskatoon Field Notes 25:1. 
${ }^{39}$ POTTER, L. B. 1943. Saskatchewan bird records made since the publication of Mitchell's Catalogue of Saskatchewan Birds in 1924. Blue Jay 1:25.

${ }^{40}$ RIOME, S. D. 1971. Sight records of the Common Scoter in Saskatchewan. Blue Jay 29:31-32.

${ }^{41}$ ROBERTSON, W. B., Jr. 1978. The Changing Seasons - the 1978 nesting season in North America. American Birds 32:1128-1136.

41 a ROBINS, C. S., B. BRUUN and H. S. ZIM. 1966. Birds of North America. Golden Press, New York.

${ }^{42}$ SERR, E. M. 1976. Northern Great Plains Region. American Birds 30:87-90.

${ }^{43}$ SERR, ESTHER M. 1976. Northern Great Plains Region. American Birds 30:855858.

${ }^{44}$ SERR, E. M. 1977. Northern Great Plains Region. American Birds 31:190-194.

${ }^{45}$ SERR, E. M. 1977. Northern Great Plains Region. American Birds 31:1013-1016.

${ }^{46}$ SERR, ESTHER M. 1977. Northern Great Plains Region. American Birds 31:1150-1154.

${ }^{47}$ SERR, E. M. 1978. Northern Great Plains Region. American Birds 32:1175-1178.
${ }^{48}$ SERR, E. M. 1979. Northern Great Plains Region. American Birds 33:188-191.

${ }^{49}$ SHADICK, S. J., and B. LUTERBACH. 1980. Saskatchewan breeding records for Red Crossbill, Orchard Oriole and Red-headed Woodpecker. Blue Jay 38:247-249.

${ }^{50}$ SMITH, HARLAN I. 1914. Handbook of the Rocky Mountains Park Museum. Government Printing Bureau, Ottawa.

${ }^{5}$ STEIN, ROBERT C. 1963. Isolating mechanisms between populations of Traill's Flycatchers. Proc. Amer. Phil. Soc. 107:21-50.

51a TAVERNER, P.A. 1943. The birds of Canada, Mission Co., Toronto.

${ }^{52}$ WEBER, W. C. 1971. Sight record of a Snowy Egret at Cypress Lake, Saskatchewan. Blue Jay 29:134-315.

${ }^{53}$ WEIDL, D. 1979. Snowy Egret at Crooked Lake, Saskatchewan. Blue Jay 37:53.

${ }^{54}$ WILKINSON, J. 1977. First record of a Summer Tanager in Saskatchewan. Blue Jay 35:87-88.

${ }^{55}$ YORKTON NATURAL HISTORY SOCIETY. 1947. Check-list of Saskatchewan birds. Yorkton Natural History Society, Yorkton.

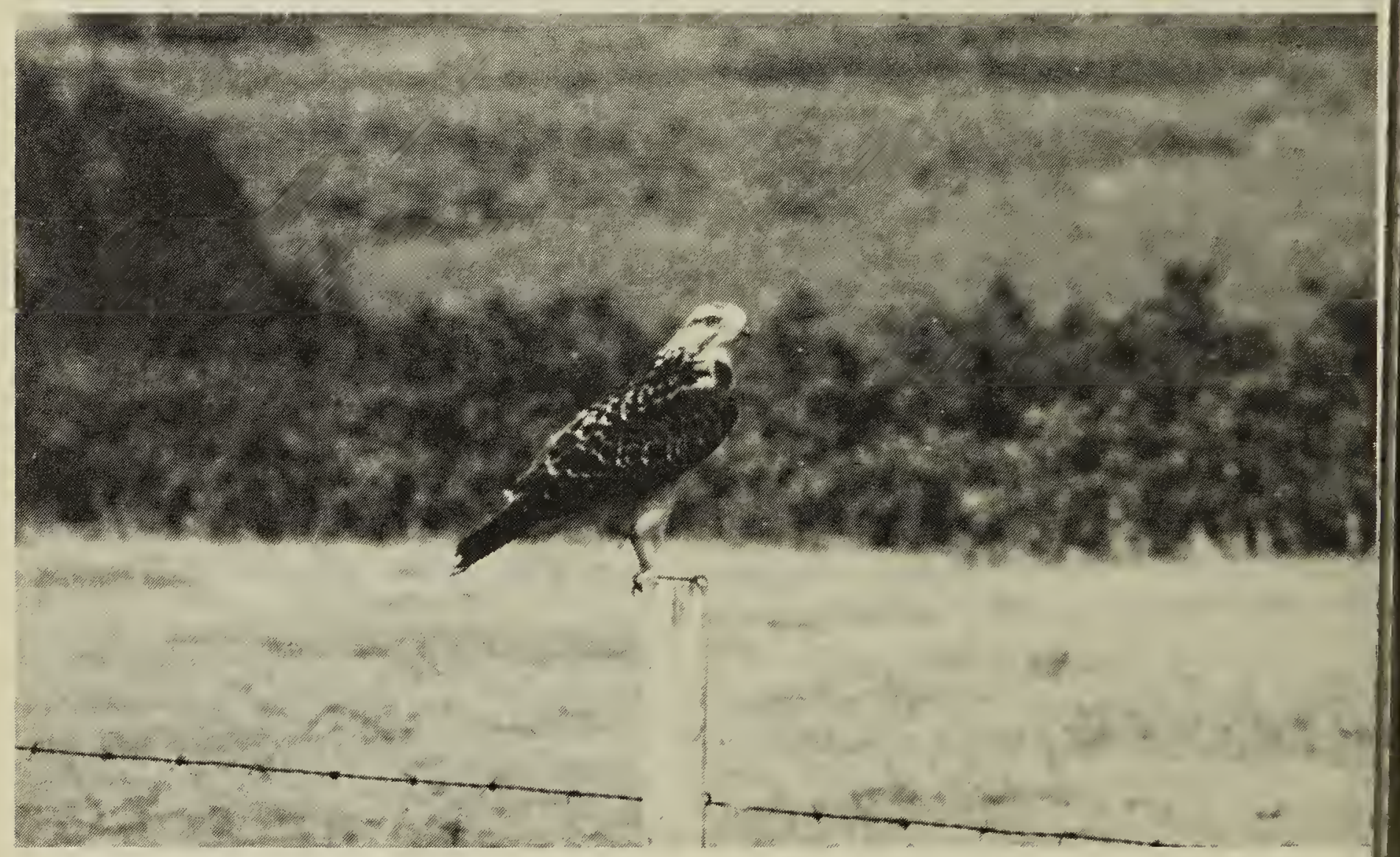

